\section{Breaking through the bondage of abuse: Case studies of six Filipino battered women}

\author{
Abulon, Edna Luz R. $\bowtie$ \\ Philippine Normal University, Philippines (abulon.elv@pnu.edu.ph)
}

Received: 1 June 2014

Available Online: 23 July 2014

Revised: 9 July 2014

DOI: $10.5861 /$ ijrsp.2014.865

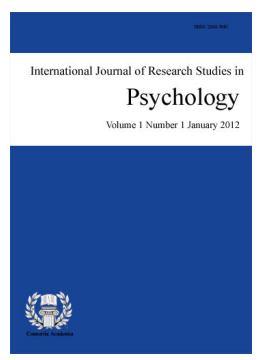

Accepted: 10 July 2014 Online ISSN: 2243-769X

OPEN ACCESS

\title{
Abstract
}

Spousal abuse is a social problem that pervades many societies worldwide. Breaking through such bondage was indeed a memorable saga as depicted in this study. Six women described their experiences of abuse and their respective life trajectories towards freedom and recovery. The study further draws implications of this phenomenon to counseling, women advocacy and tertiary education; and eventually offered a theoretical framework of the breaking through process. This investigation utilized the case study approach, using the in-depth interview method. Six women between 28 to 57 years old participated in this study. All of them were married but left their husbands. They experienced the cycle of abuse from 2 to 28 years. The case studies show how the six women lived a tormented life in the hands of the ones who give them sweet and everlasting promises. Their traumatic experience nevertheless propelled them to demonstrate resiliency which enables them to survive the trauma and recover from it. In the breaking through process, the availability of social support was found to be very important. The recovery stage commenced after women leave the cycle of abuse. Their endurance of the spousal abuse for years allows them to develop and push advocacies to help other women who share the same experiences. Through the rediscovery of the self, battered women are able to highlight their own strengths, thus, were able to craft a new concept of the self through self- empowerment.

Keywords: spousal abuse; self-concept; resiliency; social support; self-empowerment 


\section{Breaking through the bondage of abuse: Case studies of six Filipino battered women}

\section{Introduction}

Violence is an ever increasing social problem world-wide. It happens not only in the streets but inside the most basic unit of the society - the family. Violence inside the family is known as domestic violence. Domestic violence is a universal phenomenon that can occur in every group or culture. It is defined as violence within the family environment, specifically perpetrated by intimate partners and includes acts such as physical maltreatment or assault, repeated verbal abuse, emotional and physical threats, sexual molestation and forced sex, emotional neglect, material deprivation and other forms of abuses (Ramiro et al., 2004).

In this social context, women deserve a special focus as they become predominantly more likely to be disadvantaged compared with men. They are the primary victims and the secondary victims are children.

As noted by the United Nations:

Violence against women is the manifestation of historically unequal power relations between men and women, which have led to domination over and discrimination against women by men and to the prevention of the full advancement of women. Domestic violence is gender-based violence perpetrated by an intimate partner and which include physical, sexual, psychological and economic abuse. It is considered to be a global epidemic that kills, tortures and maims women all over the world (The United Nations Declaration on the Elimination of Violence against Women 1993 in a publication by Woman's Aid 2001).

Violence against women rooted in a "patriarchal" system practiced thousands of years ago. In this system women seem innately inferior to men. This perceived inferiority extends to females' intellectual, spiritual, physical, sexual, and emotional lives. The tendency of men to devalue women and to see them as "property" leads to cruelty against women.

Wilson (2000) describes the scenario as follows: "at the very heart of wife battering is the subordination of women and their subjection to male control and authority, and this subordination has been institutionalized in the structure of the patriarchal family and is supported by such societal institutions as economics, politics, religion, medicine, education and culture."

The Philippines is no exception to this perennial problem. Historically, patriarchal system was practiced in the country. It viewed woman to be submissive to man. Also, traditionally, Filipinos are known to value family solidarity and cohesiveness (Quismundo, 2009). Responding to the increasing cases of family violence in the country, Carandang and Sison (2004) wrote a book that serves as a primer to understand, stop, and prevent further occurrence of family violence. Anchored on the unique Filipino way of coping "Ang sakit ng kalingkingan ay nararamdaman ng buongkatawan," the book depicted cases to trace the causes of violence perpetrated by the father. It can be gleaned from the case studies presented that one main contributing factor to physical abuse in the family is the experience of various kinds of abuse by the perpetrators themselves in their own family of origin. This pattern is termed by the authors as "intergenerational patterns." This is also applicable to the woman-partner or the mother who usually has a certain personal history that puts her in a "helpless victim" position. Carandang and Sison (2004) note that "the intergenerational patterns include having been abused physically and verbally by one or both parents or by a male sibling, having a submissive mother as role model, having experienced a series of losses and having to take care of everybody in the family."

Indubitably, abused women attempt to construe the meaning of their experience of domestic violence (Estrellado \& Salazar-Clemena, 2007; Hevern, 2008). This is one of the four essential existential goals according 
to Hevern (2008). The other three goals are focused on establishing a personal identity, predicting how intentional agents will act in the future, and how a person negotiates in his social word.

Needless to say, the prevalence of domestic violence is very alarming and warrants a thorough investigation. Hence, this study is a step toward a more thorough understanding of the lives of selected Filipino battered women. This study is academically significant as it extends the scope of present knowledge on the impact of domestic violence. Implications for counseling can be drawn from the results of the study. Likewise, possible advocacy on the plight of this specific women population can be introduced to impact gender socialization practices, among others.

Specifically, the researcher attempted to answer the following questions:

1. How the Filipino battered women described their experience of domestic violence?

2. How the Filipino battered women described the pathways toward recovery from trauma?

3. What are the cultural influences that could have brought the Filipino women to be subjected to domestic violence?

4. From the content analysis of the six cases of Filipino battered women, what vital pieces of information that served as input toward the development a theoretical framework that depicts the breaking through process?

\section{Methods}

This investigation utilized the case study approach, using the in-depth interview method. Storytelling was encouraged because it unveils the essence the participants to share their lived experiences.

Six women between 28 to 57 years old participated in this study. All of them were married but left their husbands. They experienced the cycle of abuse from 2 to 28 years. Three of them were selected upon recommendation of a Women's Desk Office in Manila and the other three were personal referrals. They were selected to become the cases to study based on the following criteria: (a) had experienced battering for at least two years of cohabitating with the partner; and (b) no longer cohabitating with the partner for at least two years from the time of the data gathering.

An unstructured interview guide was used for the data collection. The interview guide comprised six global questions; some of which had follow-up questions. The questions were fashioned to enable participants to tell stories about themselves before and during marriage and after they left their husbands.

At the start of the interview, the researcher oriented each participant on the purpose of the study. Each participant was informed that the interview would be audio taped as explicitly stated in the consent form. The interview session with the six participants which were held in a private professional's clinic in Manila averaged three hours. The interview proceedings were transcribed verbatim for data analysis.

The data analysis consisted of two phases. The first phase was intended for the write-up of each case which included background information, how spousal abuse was experienced, turning points toward leaving the cycle, and pathways toward recovery from the trauma. The second phase, the content analysis, followed the following steps: (1) production of the three sets of the transcriptions of the interview and independent analysis by three judges, a researcher, and two external judges who were also counselling psychologists; (2) meeting of the team and differentiation of parts of the transcriptions, identification of meaning units that organized the data; and (3) organization of the materials around themes found in the transcriptions of the interview. 


\section{Results}

This section presents the write-up of each case which includes some background information, participants' description of their lives in cycles of abuse, turning points toward leaving the cycle, the pathways toward recovery from the trauma.

\subsection{Case Study No. 1: Amor}

\section{Background Information}

Amor had a happy childhood spent in Negros Occidental. When she was seven years old she and her family moved to Bulacan where her dad was assigned in a branch of the Philippine National Bank. In her first year in Bulacan she experienced culture shock because of her regional accent. In grade three, she experienced being pinched by a classmate because her classmate hated her for her being Visayan. Later, Amor with her family, moved to Makati because they were able to buy a house there.

Amor studied in Manila from grade four until she graduated from high school. Despite enjoying the company of her elder siblings and some friends in her village, she was still quite introvert because her mother kept her from going to parties in her teens. Because of her mother's strictness, Amor grew a penchant for staying home and avoiding parties altogether. She became closer to her dad than to her mom. She always thought that her mom often got mad at her for things that she thought did not warrant a reprimand. She also thought that her mother played favoritism and was very strict.

In her elementary days, Amor was often in the top three or top five of her class but she never experienced how it was to be the first honor. In high school, she still received honors and often elected as a class officer. In college, she shifted to physical therapy (PT) when her pre-med course was about to be closed. Again, she shifted to Psychology when her professor said some physical therapists offer extra services and behave like sluts or whores in bathhouses.

She learned to love Psychology as she often liked to observe people's behavior and tried to find explanation for their behavior. She decided to pursue further studies and take up a master's degree in Psychology not only because she found her research job monotonous but also to broaden her knowledge in the discipline.

Finally, Amor felt like she was somebody. With a master's degree, she felt proud but deep inside she knew she was still shy to interact socially.

\section{A Life in the Cycle of Abuse}

She met her boyfriend at the church choir. She was taking up her master's degree then. Because of her parents' strictness, she had limited interactions with boys. Thus, she had no interest in men until she met her boyfriend.

It was New Year's day when Amor answered the guy and they became couple. Her boyfriend enjoyed going out in group dates. He got easily bored when only the two of them were together. He was fond of going out with friends, eating out, and watching movies. They never planned or talked about their future. At that time, Amor knew very little about his character. Their mutual friends made insinuations about his temper but they never told Amor anything. When they were still going out her boyfriend already showed signs of sensitivity and jealousy.

Amor and her boyfriend were together for four years. On their fourth year, Amor's boyfriend changed. He started to get protective. He used his parents' migrating abroad as an excuse to get married hurriedly. Hence, they got married. Later, Amor learned his parents were not migrating and he just wanted to have someone take care of him. Since her husband was still studying and she barely had any savings as she had just started working, they were financially incapable. As a result, she relied on her in-laws for financial support. Amor was 25 then and her 
husband, 23.

Things got worse six months after their marriage. Amor's husband would often call her demeaning names like stupid and incompetent. He shouted at her when he could not find his things. When he was even more riled up, he would hit her. Slowly, her self-confidence diminished.

The first slap she got was when they got lost looking for a field trip site. Amor accidentally got the wrong directions - she told her husband to turn right instead of turning left. He started getting quiet as they made their way home. When they were almost home, Amor's husband reprimanded her and out of the blue he slapped her. After the incident Amor went to her parents' house in Makati. Amor's dad saw her face but he did not say anything. At around three o'clock in the afternoon, her mother in-law called and told that her husband had not eaten yet. Feeling guilty, Amor went home. When she arrived home she saw him holding a letter from her sister asking her to teach as pre-school teacher in Canada. Furious, her husband pushed her away saying "Go, leave me!" Amor said sorry repeatedly. She did not leave.

They all objected when she wanted to put up a pre-school. She went ahead anyway. During meetings with the incorporators he would pick her up. He would usually arrive early and incessantly honk the horn. Amor was always terrified. One time, he picked her up early because he wanted her to cook his meals. But the funny thing was his mother wanted to cook all his meals. Amor was caught in the middle. For years, she had to traverse the thin line of pleasing him and his mother.

The abuse had escalated. He would punch, hit, and shout at her. She showed bruises in her eyes and body. In two years of living together, they did not have a child. She prayed to have one hoping that it would ease her burden and please her husband. But when she got pregnant his cruelty did not wane away. He even hit her in the stomach.

When the first baby was born, he seemed to be caring. He would wake up at night to feed the baby. He worked in a clinic during the day so Amor decided to take care of the baby at night. He started to sleep in the other room and eventually he stopped taking care of their baby.

Three years later, their second baby arrived. But his frustration of having another girl irked him more. He wanted to have a son. This aggravated his temper toward Amor. He once hit Amor with a car door and broke the aluminum door of their house because he hit it when he was extremely infuriated.

There were many restrictions when the kids were growing up. They should come home on time. When boyfriends would come over, the helper should watch closely. Even Amor was not allowed to go out unless she asked permission. Amor had to call or send him a beep to inform him of her whereabouts, who she was with, who she was visiting, and what she was doing.

Also, Amor suffered economic abuse under him. When they had just started living together they had common funds. But later on, Amor was required to give a detailed account of all her expenses including all the grocery and market expenses down to the last centavo. If Amor had money, it was deemed "our money" by her husband. But when the money came from his family, it was only "their money."

\section{Turning Points toward Leaving the Cycle of Abuse}

He started seeing another woman after their second child was born. The woman was their good friend. In fact, she was the godmother of Amor's youngest and Amor of the woman's eldest. Their children were classmates in school. The children were particularly affected when they found out their dad was spending time with the other woman's children as well.

On and off, Amor's husband and his mistress were together for almost 10 years. The woman separated from her husband, who was also her friend. Amor learned from her husband's secretary that he had a house built for 
her. Her husband even sent his mistress to the United States in hopes that they could possibly move there. Unfortunately, she did not find a job there so she had to return. Since then, he stood as the surrogate father for his mistress' children.

One time, he got infuriated when Amor came late from an interview with an applicant so he tried to hit Amor with a car. The board members in the preschool witnessed the whole scenario and they bluntly told Amor to leave him but she did not listen to them. He threatened Amor several times that he would kill her. Depressed, Amor attempted twice to take her own life. She felt isolated. She finally left her husband when her mother-in-law died and when children were already grown-ups.

\section{Pathways toward Recovery from Trauma}

Amor pursued her studies and finished her doctoral degree. She realized she was not stupid like what her husband often told her. She regained her confidence.

She considers her mother, her two daughters, and her siblings as the most important people in her life. They were very supportive of her and they all agreed she was a very patient, kind, and forbearing person.

Amor still has dreams of having a house, a car, and a small business of her own to support her when she gets old. She is now content with her education as she is able to combine her two passions: psychology and education. She wants to drive again. She can drive but she was just discouraged by her husband.

Back then, her dreams were to give her children a good education and properly raise them. They were the reason she could not leave her husband because she was jobless and penniless.

When Amor was young she dreamt of having a good education and now she has achieved it. Now she wants to form a support group for women, build a child-care center, and attend yoga classes. She is currently involved in training teachers in math and in English.

Amor says she does not dream of becoming anyone else but herself. Despite all the hardships, she rose up to where she is now. She is now able to smile and breathe freely. If she were to look back at her life experiences, she would not wish to go through her life again. It was a hell.

\subsection{Case Study No. 2: Inah}

\section{Background Information}

Inah grew up in Leyte. Her mom went to marry another man and left her in the care of her grandmother. She never saw her dad until she was five years old. Since then, he never showed up again. At 19, when her grandmother died, she was left to wander by herself to find a place to live.

Having been raised by her conservative grandmother, she described herself as kind, humble, and patient woman who can withstand anything. She was often weak and submissive to everyone around her especially to men and their advances. When she was younger, men would pine and court her. She was almost raped when she was seven. But she was not lucky enough when she was 15 . It resulted in a baby girl who is now 25 , married, and with two children.

\section{A Life in the Cycle of Abuse}

She met her husband when a mutual friend introduced him to her over drinks. Since Inah was not a strong drinker, she found herself drunk and naked the following morning. She got pregnant. She did not like him to be her husband but she agreed to avoid embarrassment.

She was 29 when she got married in 1999. Inah did all the household chores. They lived near her mother-in-law's house and every time her husband came back from there they fought. 
When her husband was jobless, Inah had to find any job like washing their neighbors' clothes and working at a canteen at night just to feed their children. Despite her hard work, her husband would shout at her every time she would come home late, thinking that she was entertaining other guys.

Her husband was assigned in Mindanao and there he had a mistress. This stopped him from sending her money for the children. To make ends meet, Inah had to borrow money from her sister. Whenever her husband came back from Mindanao, he was always angry or in foul mood. The shouting progressed to slapping and pushing.

\section{Turning Points toward Leaving the Cycle of Abuse}

In 2009, Inah and her husband fought over the lost keys. This time, he did not just shout; he beat Inah to a pulp. She could no longer walk. Her children accompanied her to the baranggay hall and the baranggay officials brought her to a hospital nearby. When she got better, she found out a knife hidden under her bed. She was sure that if she had not gotten out that day, she and her children would have been killed by her husband.

Another major reason why Inah would not reconcile with her husband was when her two daughters were molested by their uncle and she was helpless about it. She felt guilty when she could not protect her children from the molestations of her husband's drinking buddies. Now the children are under her custody. Her youngest child lives with her eldest daughter and her family.

\section{Pathways toward Recovery from Trauma}

The Women's Desk Office advised Inah to undergo therapy. At first, she was hesitant and lost faith in herself. But she knew she had to to move on with her life. Unless she could prove she had permanent residence and could provide the basic needs for her two children, the Department of Social Welfare and Development (DSWD) disallowed her from claiming custody for her children.

Because of her children, Inah felt even more empowered and driven to be with the children again. She worked hard as beauty products dealer. Although she did not fulfill her dream to be a nurse, all she wished for was for her children to finish their studies. Inah said the ordeal challenged her to raise the children by herself. After 11 years of being submissive to a man who battered her, she promised herself not to be with another man anymore.

Now at 40, Inah is in a new relationship with a woman named Kathy who helps her to get back on her feet. When Kathy went to Bahrain, she sent her money. Inah said she no longer cries every time she is faced with a problem. She now knows how to fight back and face her problems squarely.

\subsection{Case Study No. 3: Georgia}

\section{Background Information}

Georgia had just turned 18 when her mom asked her to marry her childhood sweetheart. She did not even reach college and had only finished second year in high school. It was in 1992 when she gave in to her mother's request to marry the guy.

She soon gave birth to the first of her 12 children. Triplets followed but died. Shortly after, she gave birth to another two. In 1998 after having lived all her life in Catanduanes, she moved to Bulacan to be with her husband who went there to work in an export cannery. Georgia stayed at her nieces' place for some time before she and her children moved to her aunt's place in Quezon City. Shortly after, her mom followed her there and Georgia found it convenient to leave the children with her mom so she could work. In 1999, 2000 and 2001 she gave birth to three. In 2003, 2004 and 2006, she gave birth to three more.

Georgia realized that she was good at doing "sales pitches." She excelled in selling goods of all sorts—from 
clothes and soaps to door-to-door products. She accepted laundry and pressing jobs and worked as a stay-out help. She always thought of ways to earn money to buy food for the family. Unlike her husband, she scrimped and saved her earnings for the future of her children.

\section{A Life in the Cycle of Abuse}

Early on their relationship, she described her husband as nice. This was the time when she was working in Bulacan. He would give her all his earnings every time he came home to Quezon City. He cooked excellently. He fed the children when her mom moved to the province. He cooked delicious food for Georgia and made her feel like a princess especially when he wanted to have sex with her.

He made it clear that she, as a woman, had to obey him. So even when it was painful for her to have sex, she had no choice but to obey him. Thus, it resulted in having a lot of children. If Georgia did not succumb to him, he would get angry.

Georgia's husband was ill-tempered. He was easily enraged by trivial things such as when the children were reluctant to eat their meals. Thinking of the protection of the children from his temper, Georgia ought it best to please him even it would mean ordeal on her part.

\section{Turning Points toward Leaving the Cycle of Abuse}

In 2009 everything changed. Her husband got into gambling and drugs. He no longer gave the kids attention and would often come home late and drunk. He stopped working in a cannery and took contractual jobs like a construction work. He got involved with friends who often drank. His temper worsened and his shouting became more frequent. He and Georgia would often fight because of lack of money.

One night he came home late and drunk and they got into an argument. He pulled Georgia's arm and hit her face. She got wounded. She reported the incident to the baranggay office. He promised not to do it again. But he did. Fortunately she had a number of a social worker and his husband was immediately sent to jail. But because the case was not filed immediately, he managed to bail. She filed a case and left their house in Quezon City because the children were already getting scared of him. Seven of her children went with her and all of them moved to the shelters.

\section{Pathways toward Recovery from the Trauma}

Georgia's first court hearing was held at the Quezon City Hall three months after she filed a case against her husband. She is currently renting a room in Caloocan while visiting her children at the shelters whenever she could. It has been two years since she separated from her husband. She is still trying to make ends meet so she could finally take her kids from the shelter and all of them could be together again.

If the DSWD could help her with the fares, she would take all the kids to her mom in the province. She is also seeking for financial support from her husband.

If there is one thing Georgia would really want, it is the education of her children.

She dreams of becoming a social worker someday because she says that there is joy in helping other people. It was only in the women's shelter that she learned about women's rights. She realized that, under any circumstances, a woman should not be abused. She vowed never to return to her husband.

She tells the women at the shelter one important lesson: "Taking your own life is never a solution to anything. Don't ever do it." 
3.4 Case Study No. 4: Cristy

\section{Background Information}

Cristy was the youngest in a brood of three. All of them went to exclusive schools for their elementary and high school education. And when her siblings went to the University of Santo Tomas for college, Cristy wanted to follow as well. But her parents wanted her to work at their family-run photography studio. Despite her parents' disapproval, Cristy went to UST and pushed herself to become a self-supporting scholar. She left her parents' house and put up a business while studying. She earned a lot as a writer and a graphic design artist.

After attending in an all-girls school, she was excited but quite inexperienced when it came to boys and relationships. She met her boyfriend and they lived together for seven years. She supported both of them with the money she got from her business. When she got pregnant, she had to stop working because her pregnancy was sensitive. She was almost about to give birth when she and her boyfriend decided to get married. She was 23 then.

\section{A Life in the Cycle of Abuse}

Cristy described herself as a very strong woman. She put herself to school and lived by her own means.The marriage was not at all her idea. She felt that she was pushed into it. Since she could not walk during her pregnancy, she was in a wheelchair and incapacitated. She felt her husband took advantage of the situation and she could not muster any strength to object. Shortly after, she lost her outgoing nature and felt that she was treated like a prisoner. She felt useless. She also learned her husband had other women. His sexual appetite was insatiable. He wanted multiple partners.

Cristy was exhausted taking care of their son and doing all the household chores during the day. But she still had to have sex with him every night or whenever he wanted. He became violent if she would resist. He physically abused her and treated her like a doll to do all what he pleased. His desires were animalistic. He did not care whether Cristy would cry in pain or lose consciousness. He was totally insensitive to her. She felt like she could die without him noticing it.

\section{Turning Points toward Leaving the Cycle of Abuse}

At first, she thought she was the only one being abused. But when her son turned three, she found out that her husband was sexually abusing him as well. Her son would remember all the things her husband would do to him whenever she was away.

Cristy was furious. She could not take it any longer. She filed a case against her husband. He was served a warrant of arrest and was picked up by the police.

\section{Pathways toward Recovery from Trauma}

She brought her son to the Child Protection Unit of a hospital. It enabled her to successfully move on. Cristy underwent continuous therapy and was referred by a psychiatrist to a trauma section to address the memories in her subconscious.

She moved back to her family's house and had since reconciled grievances with her whole family. She used to be so mad at her parents but realized that the reason they did not want her to go was she was the 'apple of the eye' of her dad. They did not want her to live way from them. Her relationship with her dad and mom became stronger than ever. Cristy's elder brother was like a dad to her son. Cristy's elder sister started to give her emotional support.

Two years after her husband was jailed, Cristy thought of moving back to their residence just in case her husband would bother her again. 
All that Cristy would ask for is the provision of his son's needs and education and good health for her parents as they get older. Cristy still dreams of becoming a painter. She also dreams of having a business after her court case. She wants to put up a coffee shop where she could also showcase her artworks.

\subsection{Case Study No. 5: Misty}

\section{Background Information}

During her younger days, Misty was attractive and had a strong presence. She described herself as hardworking and persevering especially when she was a student.

She met her husband, Boy, when they were in third year high school at a private school in the province. They were often teased, but no relationship ever materialized. When she was in fourth year high school, she had to transfer to another private school. Though she was in another school, Boy often visited her. She thought it was just normal because they were friends.

She went to college in the province and took a course in commerce majoring in accounting. In her third year, her parents moved to Canada so she also had to move to Manila to stay with her aunt and study in a private university where her aunt worked. There she met a friend who was her neighbor before. They became close. But when Boy found it out he was crestfallen. He asked her to live together.

\section{A Life in the Cycle of Abuse}

Shortly after they lived together, she got pregnant. She was 22 then. Because she had a brother who was a priest and a sister who was a nun, there was no questioning about their getting married.

Boy was a smart and intelligent man, a good provider but an ill-tempered person. On the day of their wedding, somebody brought chickens to their house as a wedding present. Boy asked Misty to take them inside. But because she was busy ironing his shirt for the wedding rites, she told him to ask someone else. This irked Boy and he shouted at her in front of all her friends. Terribly embarrassed, Misty cried and felt bad about herself. But he threatened Misty to call off the wedding if she would not stop crying.

When she gave birth to their eldest daughter, Boy's temper and shouting bouts worsened. Every time she answered back to him, he would slap her. Often, Misty would confide these things to her nun sister and both of them would cry. Her sister would advise her to "wade it out" and to be more patient in hopes that Boy would eventually change. But Boy would often curse Misty and say demeaning words like "Demonyo ka" (You are a devil!). His frequent cursing eroded Misty's self-esteem.

No matter where Boy and Misty went—in the province, Manila and even in Brunei when they live there for a while-there was not a day they did not argue. For the smallest things she showed defiance, Boy would slap her. Also, Boy controlled all their money. So, to buy smallest thing in the household, she had to ask Boy. But he never gave her money anymore. He had the money. He was the authority. All the decisions were his.

After Misty gave birth to their second child, she quit her job because arriving home late made Boy more furious. He thought Misty was meeting other men.

Misty promised herself that when her children turn 21 she would leave Boy. For the mean time, she opted to weather all his abuses so that the children would grow up with a father. She consoled herself that, despite of his being abusive, he was a good provider.

Misty persuaded Boy to go with her for professional counseling. But despite being counseled for 10 years, things did not change much. Boy still hurt her physically every time they argued. He wooed her with expensive stuffs but the cycle of abuse still continued. 


\section{Turning Points toward Leaving the Cycle of Abuse}

They had an intense argument where Boy kept cussing. Misty answered back with a defiant cuss. Boy was surprised and taken aback where she got her language. That was the start of Misty's strong attitude. Not long after, they had another intense argument and Boy shouted for her to leave. Misty refused. When Boy went to stand up and leave instead, Misty barred the door with her body and exclaimed he could go ahead or kill her if he wanted to.

After 22 years of enduring the ordeal, she finally filed an annulment case against her husband. When the psychologist asked why Misty allowed herself to endure his maltreatment, she said because of their children. She did not want to leave them at such a very young age. She filed an annulment case in her hometown and asked nothing for his 20 million worth of properties and estate. She was 43

\section{Pathways toward Recovery from Trauma}

During the time she was with Boy she really lost her freedom-as a wife and as a woman. She felt like being in prison.

When Misty left, she had to start her life from scratch. It helped that her kids were old enough so she did not have to worry much about them. She left her children with Boy deciding that they would have a better life with their father because he could provide better for them. Besides, he had the house. She instead busied herself with a farm which she converted it to a subdivision. She sold it and earned profit. Now at 53, almost 10 years since she left with nothing, she is thriving.

The love and respect she learned from her parents truly inspired her. Also, her parents taught her and her siblings the virtue of patience, forgiveness, and understanding.

Misty believes that if a woman really loves herself, she would not allow any physical, verbal, or psychological abuse to be intended to her. It is the respect and love for herself that will make her stand up and assert her rights.

\subsection{Case Study No. 6: Iris}

\section{Background Information}

Iris seemed like an epitome of intelligence and strength. She graduated from one of the prominent schools in the country and was a consistent deans' lister. She was an active member and officer of a famous chorale in her university. She went to the United States and Malaysia to sing and after coming back she found herself performing in musicals, gigs, and events. She was even one of the top 24 in a prestigious talent show. She belonged to a middle class family so it seemed like she needed not to worry about anything.

\section{A Life in the Cycle of Abuse}

When Iris was first introduced to Pierre, she was actually in a relationship with a much older Australian divorcee who had two kids. Given the long distance relationship and age difference, Iris thought it was a wise decision for her to choose Pierre and end her relationship with her Australian beau since Pierre seemed to easily fulfill her needs at that time. Everything seemed to point at the right direction. So despite her parents' strong disapproval of their relationship, she packed up and went with Pierre.

Barely three months in their relationship, Pierre slapped Iris. Pierre did it because, according to him, he just wanted her to "feel the pain he was feeling." A year after she had given birth to their first child, the slapping escalated to kicking, punching, pulling her hair, and dragging her across the floor. She was physically and verbally abused in front for their son. When she was four months pregnant with their second child, Pierre hurt Iris. She got multiple injuries in her arms, legs, thighs, and ribs. She busted her lip and broke her finger when she 
was dragged by her legs across the floor. Months later, in the middle of the night, because of an argument, he hit her on the head and slammed her skull on the wall and on the bedroom door which kept her from leaving the house for days to heal her bruised and swollen face. Despite what she got, she was blamed for allowing such incident to happen which kept her from taking out their children for afternoon strolls.

\section{Turning Points toward Leaving the Cycle of Abuse}

Iris did not have any family or friends to turn to. The only person she confided about the physical, verbal, and psychological abuse was Pierre's mom, who, she later learned, had also suffered similar abuse from her new husband. Iris realized that Pierre's apparent disrespect for women seemed to stem from his mother's being submissive to her husband, Pierre's step-father. Pierre had also suffered verbal and physical abuse from his step father while his mother just stood by.

Iris thought she deserved such maltreatment from her husband because she was sexually abused by her granduncle when she was seven.

Besides the physical and psychological abuses she suffered from her husband, was her husband's blatant womanizing which she could not accept. He had sexual relations with seven women and the last straw a 19-year old girl whom he refused to break up with despite Iris' persistent request. They met almost every day and spent hours in motels. Iris felt that she was enslaved to take care of the children. She was not given money and allowed to go out with friends.

It was only in January of 2012 that she reconnected with her friend Evelyn with whom she confided what she was going through. Evelyn kept in touch with her and gave her emotional support. Slowly, Iris regained her confidence and realized that she was a strong and intelligent person capable of doing anything. With Evelyn's strong emotional support, she finally left Pierre. With her two children, she sneaked out of their residence in May 2012. It was also her twin sister who helped her overcome her ordeal.

\section{Pathways toward Recovery from Trauma}

Iris admitted that she found it hard to leave her husband because of their children and because she was afraid she would not be able to give them a better future.

Shortly after she left her husband, Iris found a job, got an apartment, and found a new school for his eldest son. She has sought therapy for her and for her children. She is now going through multiple court cases filed against her husband and one of which is seeking for a Permanent Protection Order from him for the children.

Iris has reconnected with her whole family and her relationship with her mom became stronger than ever. Iris wishes nothing but an open and trusting relationship with her children built on love, respect, and kindness.

\section{Discussion}

The study looked deeply into how the six women described their lives with their abusive partners. It further attempted to identify some cultural influences that could have subjected Filipino women to victims of domestic violence. Most importantly, the study captured the turning points which made these battered women decide to leave their husbands and the pathways toward their recovery from their traumatic lives.

\subsection{A Life in a Cycle of Abuse}

All the women in the case studies experienced physical and psychological abuse. The women unanimously characterized the abusive relationship as relationship surrounded by power and control. The husband's seeming omnipotence over women made these women submit themselves almost without question. Thus, the women described themselves as very submissive and resilient during the course of their marriages. As the women discovered their resilience, they were able to survive the pain and turmoil of domestic violence. These changes 
enabled them to cope with the cyclical nature of abuse inflicted by their husbands during the course of their marriages.

The consequences of abuse are alarming. All of the women shared that their self-worth was gravely affected. The frequent name calling, labeling, and put-downs slowly eroded their self-esteem. Considering that four in the six participants were well-educated, the effect of name calling and put-downs on their self-worth was profoundly devastating.

The stories further exemplify how the six women lost control of their thoughts and emotions as they faced the dilemma in an abusive relationship. Cristy and Misty saw themselves like prisoners, enduring all the abuses perpetrated by their husbands. Misty admitted she completely lost her freedom. Cristy held that she used to be a cheerful person but at the time of violence she lost the trait and suddenly saw herself like a prisoner. She further shared that before she got married, her personhood was whole. She was so certain of herself that she could anticipate what would happen, but when she lived with her husband, all of a sudden, everything seemed too uncertain. Inah after discovering that her two daughters were molested by her husband and his peers felt as though she stumbled, sunk farther into the ground, and lost her mind. Amor recalled she attempted to commit suicide twice because of depression.

The majority of the responses suggest that these women were like servants in performing their tasks as wives. They performed their duties like servants and they had become numb of the power-play schemes of their husbands. Amor and Cristy gave up their careers and stayed at home. Misty said she was like a handmaid of a king - not even an employee because she did not receive any salary. She did all what her husband asked her to do. She did not even have the courage to refuse sex.

The role and identity of being a mother were severely affected by the spousal abuse. The respondents placed their children's welfare over their own despite their educational attainment and career. Their sufferings blinded them from making wise decision such as leaving their abusive husbands. The children were their primary reason why they stayed and kept their relationships. Their being mother obscured their judgments which further resulted in confusion, submission, or passivity.

\subsection{Cultural Influences That Could Have Predisposed Filipino Women to Spousal Abuse}

In the six cases studied, apparently, the major underlying theme was the loss of power, both over own life and family. The submission of power to husband, willingly or unwillingly, may have been dictated by the Filipino culture which emphasizes the preference for and dominance of males over females. Indeed, as Liwag et al. (1999) notes, in the Philippine society, both genders agree that being male means having more privileges, freedom, and power.

The majority of the women who participated in the study viewed their husband as somebody who was strong and superior to them. This made them feel inadequate and weak as women. This superiority is also related to the concept of "machismo." Nadal (2011) defines machismo as the belief in the superiority of males over females which means that men are expected to be strong, uphold rigid gender roles, and are likely to possess sexist attitude toward women. The concept began during the Spanish colonial rule, when it was common for Filipino women to be raped and beaten by Spanish friars.

The "machismo" for most Filipino men somehow allows them to make advances to Filipino women. In return, the "subordinating" role of women permitted them to endure various forms of abuse mostly perpetrated by their intimate partners.

This "machismo" has also caused Filipino women subjugation, as reflected in the narratives of the six women in the study. All of their husbands displayed the "machismo" attitude which pushed them to submit completely. This concept enabled the Filipino men to regard women as "objects." Objectification of women in 
the feminist perspective involves the act of disregarding the personal and intellectual abilities and capabilities of a female and reducing a woman's worth or role in society to that of an instrument for the sexual pleasure that she can produce in another. This was evident in the case of Cristy who considered herself as "toy" to be played with by her husband and in the case of Misty who called herself as "stuff" which can be discarded anytime by her husband.

Lastly, the survival instinct of Filipinos which is manifested in the capacity to endure despite hard times and the ability to get by with what is available in the environment enabled the Filipino wives to tolerate the occurrence of domestic violence. This is evident in the case of Georgia when she related that she knew how to cope with life to feed her children.

\subsection{How Women Break from the Bondage of Abuse: A Framework for Change}

From the case studies of the six women who were able to free themselves from the bondage of abuse, the following tipping points were evident:

a. When the abuse became so severe and too varied that they could no longer bear the pain. This happened to the four women who pursued court cases against their husbands. Their turning points, however, differed. Inah sought help from the barangay officials during the night she was beaten violently. She was then brought to the hospital for treatment. Georgia and her children were rescued by a community social worker who immediately responded to her text message. Cristy, without the knowledge of her husband, worked for the issuance of a warrant of arrest against her sexually-perverted husband. Iris asked the help of her best friend to escape with her two kids.

b. When the children were also victims of abuse. This happened to Inah whose two daughters were molested by their father and his peers. This also happened to Cristy who discovered that her only son was molested by her husband. It prompted her to file criminal charges against him.

c. When the children reached the age of maturity and finished schooling: This happened to Amor and Misty. Both of them waited for more than two decades to finally be emancipated from their marriages. They endured the physical and psychological pain of domestic violence just to ensure that their children grew up with a father figure at home and experience comfortable lives as provided by their abusive but financially-capable husbands.

From these critical points, the six women evolved and viewed themselves differently. Evidently, their view of themselves changed from having "fragmented selves" to "becoming whole once again." But, becoming "whole" again was not an immediate effect of leaving their marriages. Based on the data analyzed, several factors contributed to this phenomenon such as:

Support from significant people. This support came from their family of origin which made them feel accepted again despite they broke their marriage vows. Cristy, Iris, and Misty returned to their parents' home right after they left their respective marriages. Iris, on the other hand, found refuge in her best friend.

Assistance from organizations and helping professionals. This assistance was extended by government and non-government organizations for the abused women. Inah and Georgia were temporarily sheltered in the DSWD accredited agencies and underwent appropriate therapeutic intervention. Their children were also confined in separate shelters for abused children. Their experiences in these shelters helped them regain their sense of equilibrium and started life anew. Cristy also sought the help of a psychiatrist at the Office of the Women's desk to recover from trauma. She had sessions with the psychiatrist once a month while her son underwent therapeutic counseling since 2010 at the Child Protection Unit of a hospital in Manila.

With such support, the women deeply engaged in reflection which enabled them to do the following which further resulted in their recovery from the trauma of abuse: 
Realizing old dreams and aspirations. Through self-refection, the women regained their old dreams and aspirations. Cristy rekindled her passion for visual art. Amor relived her leadership qualities as she is now a school administrator and a practicing clinician. Iris returned to the singing profession and even discovered her creative writing prowess. These women have inherent capabilities and acquired skills through schooling which were stifled by their oppressive husbands. Once freed from marital bondage, they recovered their abilities which helped them regain their self-confidence.

Having new goals for themselves. The women reshaped their dreams after leaving their abusive husbands. In the case of Amor, she wanted to drive again - something which her former husband kept her from doing. She also wanted to have her own house, car, and business. Inah shared the same sentiments. She wished to have her own house so she could finally have custody of her two children. She also realized that she could lead and help others. After leaving her husband, financially, Misty started from scratch but later became a successful real estate entrepreneur. Cristy was eager to venture into a coffee shop business which also could be her venue to showcase her artworks. Setting new goals may indeed be therapeutic for these women as they allowed themselves to hope for a better future which they envision and slowly shape into reality.

Drawing strength and inspiration from their children. Georgia, Inah, and Cristy are driven to provide their children a good education without the help of their husbands. Evidently, they draw strength from their children, especially Georgia and Inah who have yet to have the custody of their children. Although her children are all grown-ups, Misty is nevertheless concerned about their well-being. She always tells her children that they should not be affected by the separation of their parents and should still respect their father.

Having an advocacy. Consistent with her professional background, Amor plans to organize a support group for women as well as to establish a child care center. Similarly, Georgia wants to go back to school to become a social worker because she finds joy in helping others. She evidently showed her love for others during her stay at the shelter. She served as speaker to battered women to encourage them to stand against their abusive husbands.

Cultivation of personal self is the underlying factor in these stories of recovery. Undergoing adversity in the form of repeated abuse and finally drawing the courage to escape from a psychologically-debilitating environment made each of the five women realize personal strengths which they never thought they had. All of them believe they have successfully transitioned from being a servant-like wife to being very independent and empowered women. From being weak-willed and overly-dependent on their husbands, the five women have evolved into women who are confident to speak in front of others to acknowledge and appreciate their courage, capabilities and talents, and to work toward the realization of their dreams. They do not see themselves only as wives or mothers but as persons with individuality. Indeed, these women who have broken the cycle of spousal abuse emerge as stronger persons who are fully aware and appreciative of their personal strengths.

Notably, the crafting of a new self in the case of each of the six women progressed quite slowly. It is apparent in their narratives that at least, after two years, their personal identity gradually overshadowed their other role identities like being a wife and a mother. At least, for the women in this study, breaking free from the bondage of abuse tends to be a linear process, starting from the fragmentation of the self to the realization that they are capable of positive life changes to make themselves whole again. This metamorphosis is summarized in Figure 1.

\section{Implications}

Based on the preceding results and discussion, it can be surmised that the women-victims of domestic violence were able to break free from the bondage of abuse in a very gradual and painful manner that needed social support and professional intervention. Hence, for counselors who deal with women who decide to leave their abusive husbands, the focus should be on the restoration of the victims' self-worth and enhancement of their role identities as women, wives, and mothers. 
For counselors who deal with clients who are still in the cycle of abuse, it is crucial to respect the battered women's decision to stay with their husbands. What is important is to make them aware of their choices in life and the assistance provided to them in the process of assessing and reassessing their situation. The counselor may also give emphasis on the importance of self-care behaviors (e.g. reading books, exercising, and consultation with medical doctors), as well as on building social support from friends and relatives while the clients still live in an abusive relationships.

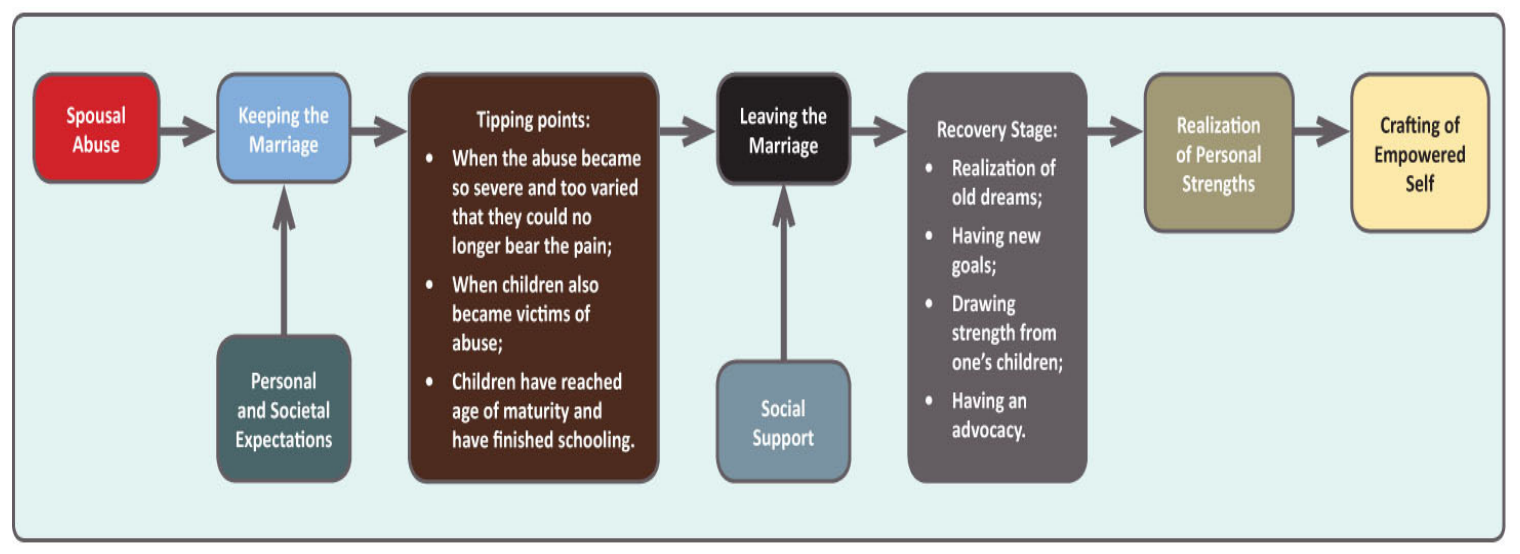

Figure 1. Framework for change

As a preventive measure on violence against women, specifically intimate partner violence, concerned authorities should push stronger advocacies to include a massive campaign through nationwide information dissemination (through print or digital media) about the RA 9262 otherwise known as "An Act Defining Violence against Women and Their Children."

In the tertiary level, preventive education can be implemented through a mandatory teaching of the "General Sociology with Family Planning" which will include topics on the local and global prevalence of domestic violence. This could heighten the awareness of the youth about this crucial societal problem. Also, the topic on "how to make good decisions about mates" can be discussed in the General Psychology course (particularly on the discussion about emotion and motivation) to provide the youth with better perspectives about choosing their future life-time partners.

The focus of the domains of both research and counseling/therapy has always been on battered women-the effects of abuse, in particular, and on the resolution of their issues and recovery from trauma and stress. Contrastingly, less focus is placed on the effects of exposure to spousal abuse on the children of battered women. There is evidence in current literature that children of battered women are likely to manifest symptoms of significant stress. It is therefore imperative that mental health practitioners attend to the needs of the children. Moreover, the research community ought to investigate the following: (a) factors that help these children to foster resiliency to the stresses caused by repeated exposure to domestic violence, and (b) whether children's concept of the self change as a result of exposure to domestic violence.

\section{Conclusions}

The case studies show how the six women live a tormented life in the hands of the ones who give them sweet and everlasting promises. Their traumatic experience of domestic violence nevertheless propels them to demonstrate resiliency which enables them to survive the trauma and recover from it.

Upon experiencing spousal abuse, battered women in this study engage in constant and deep deliberation whether they should leave their respective marriages. Personal and societal expectations play a major role in their decision making. To some degree, Filipino culture helps to abet their predicament.

There are, however, some tipping points which force the battered women to leave their marriages for good. 
One is absolutely life threatening-the ruthless abuse intended to these women which necessitate the intervention of the authorities like medical doctors, social workers, and police officers. Others pertain to prioritizing the children's well-being over their own. These women have to choose whether to withstand the pains of their marriage until the children mature and finish schooling or leave when the children become victims of domestic abuse.

In the breaking through process, the availability of social support is of paramount importance. For one, most of victims face immense financial burdens. Some of them have to surrender their own children under the custody of their abusive husbands or entrust them to the state's social welfare agency. Their other social needs include legal assistance, shelter, as well as professional help from mental health practitioners for them to recover from traumatic experiences.

The recovery stage commences after women leave the cycle of abuse. During this time, they rediscover themselves through the fulfillment of old dreams and the development of new ones. They also focus on and draw strength from their children. They even fashion their dreams according to their children's needs (e.g. good home and education). Their endurance of the spousal abuse for years allows them to develop and push advocacies to help other women who share the same experiences. Through the rediscovery of the self, battered women are able to identify and highlight their own strengths. For instance, some discover innate courage and ability to lead others.

The battered women are able to craft a new concept of the self through empowerment and constant and healthy nurturing and rebuilding of self-esteem by themselves and by the caring people around them.

\section{References:}

Carandang M. \& Sison B. (2004). The path to healing, a primer on family violence. Pasig City: Anvil Publishing House, 8-10.

Estrellado A. \& Salazar-Clemena R. (2007). Dynamics of abuse: case studies of five Filipino battered women. Philippine Journal of Psychology, 40, 5-33.

Hevern, V. (2008). Why narrative psychology can't afford to ignore the body. Journal of Social, Evolutionary and Cultural Psychology, 2(4), 217-233. http://dx.doi.org/10.1037/h0099343

Liwag, M., de la Cruz, A., \& Macapagal, M. (1999). How we raise our daughters and sons: Child-rearing and gender socialization in the Philippines. United Nations Children's Fund and Ateneo Wellness Center, Quezon City: Ateneo Press

Nadal, K. (2011). Filipino American psychology: A handbook of theory, research and clinical practice. New Jersey: John Wiley and Sons. http://dx.doi.org/10.1002/9781118094747

Quismundo, T. (2009, February 2). Rise in domestic violence alarms police. The Philippine Daily Inquirer. Retrieved July 17, 2013, from the Philippine Daily Inquirer website. Retrieved from http://newsinfo.inquirer.net/breakingnews/nation/view/20090206-187867/Rise-in-domestic-violence-ala rms-police

Ramiro L. et al. (2004). Domestic violence in urban Filipino families. Asian Journal for Women's Studies, 10, 97-119.

Republic Act No. 9262 (July 28, 2003). An act defining violence against women and their children, providing for protective measures for victims, prescribing penalties therefore, and for other purposes. Retrieved from http://www.congress.gov.ph/download/ra_12/RA09262.pdf

Wilson, K. (2000). When violence begins at home: A comprehensive guide to understanding and ending domestic abuse. Alameda, California: Hunter House Inc. Publishing.

Women's aid - about domestic violence. Retrieved from http://www.womensaid.org.uk/landing_page.asp?section=000100010005 
Abulon, E. L. R. 